. ISBN 978-93-84422-77-6

2017 International Conference on Innovations in Engineering \& Technology

(ICCET-2017)

Dubai (UAE) May 10-11, 2017

\title{
Investigation on the Effect of Metallic Nanoparticles on the Performance of Solar Still
}

\author{
Deepak Kumar Murugan ${ }^{1}$, Natarajan Elumalai ${ }^{2}$ \\ ${ }^{1}$ Department of Mechanical Engineering, Velammal Engineering College, Chennai, India \\ ${ }^{2}$ Institute for Energy studies, Department of Mechanical Engineering, Anna University, Chennai, India
}

\begin{abstract}
Water is one of the greatest current and future global challenges. Due to increase in population and industrialization, the demand of potable water is growing significantly. Most of the water purification techniques depend on conventional source of energy which forces us to drive our research towards renewable energy techniques. Solar still is the simplest, eco-friendly and cost effective method to convert impure water to potable water. In this research work, the effect of nano fluids on the productivity of a single basin solar still has been analysed. The experimental investigation was carried out with two different metallic nanofluids such as Aluminium oxide $\left(\mathrm{Al}_{2} \mathrm{O}_{3}\right)$ and Copper oxide $(\mathrm{CuO})$ which resulted in an increase of $26.36 \%$ and $34.61 \%$ respectively.
\end{abstract}

Keywords: solar still, distillation, Aluminium oxide nanofluid, Copper oxide nanofluid

\section{Introduction}

The demand of potable water is increasing rapidly. Around 600 million people in this world suffer without adequate supply of potable water. The major water resource of the earth is in ocean which is not suitable for drinking. Many conventional methods are utilized to convert the brackish or impure water to potable water. All the conventional methods utilize electricity which adds up to the existing energy crisis. All these factors drove the researchers towards the invention of solar still, a very simple device for distilling water which utilizes the renewable solar energy. The primary energy source to solar still is abundant and free. Solar still is simple in construction and relatively economical. It does not require advanced skill to operate and also it is easy to maintain which employs it to be used even in rural areas. The major setback of a solar still is its low productivity. The major influential parameters of a solar still are water evaporation and condensation rate.

Researchers all over the world are trying to increase the productivity of the solar still. The productivity can be increased by increasing the temperature of the water which increases the evaporation rate or by decreasing the temperature of the condensing glass cover which enhances the condensation rate. Many solar still devices were established throughout the world recently. Though the number of solar still devices installation has increased, it has faced many challenges in its implementation as a commercial water purification system [1,2]. Prakash et al [3] conducted an experiment with aluminium, galvanized iron and glass as the basin material and the results shows that the productivity is high when aluminium is used as the basin material. Samuel Hansen et al analysed the effect of new wick materials such as water cloral fleece, wood pulp paper and polystyrene sponge on the performance of solar still and observed an increase of $69.67 \%$ while using water coral fleece [4]. Elango et al [5] compared the performance of solar still with and without water nanofluid. Various water nanofluid of zinc oxide, tin oxide and aluminium oxide were analysed. Sahota and Tiwari developed an analytical expression of the characteristic equation of passive double slope solar still for three different nanofluid [6]. Panitapu et al. [7] have 
studied the effect of adding titanium dioxide in basin water of still and studied the variations of water temperature, vapour temperature, glass inside and outside temperature during sunshine. Bhupendragupta et al [8] compared the effect of nanoparticles on the performance of a conventional solar still and modified solar still. In the modified still the inside walls were painted white to reduce the heat loss of vapour through convection.

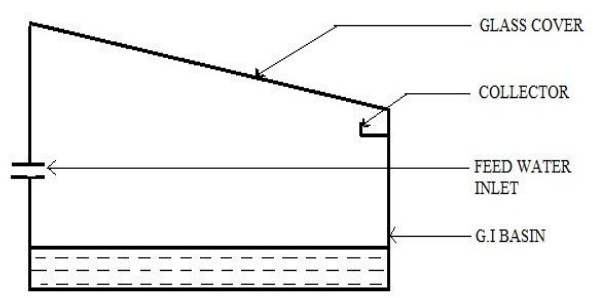

Fig.1.Schematicdiagramofsinglebasinsingleslopesolarstill.

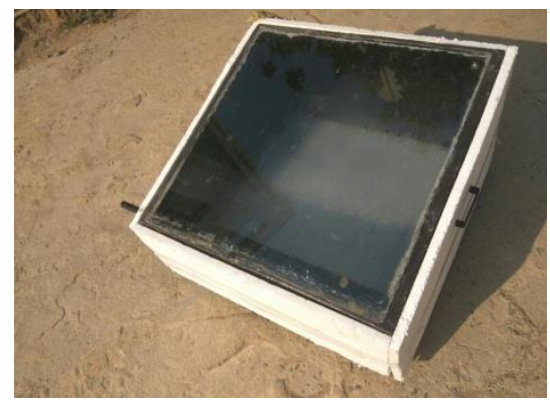

Fig 2. Experimental Setup

Thermal characteristics of the basin water greatly affect the performance of the still. The nanofluids are fluids containing nanoparticles of size 1 to $100 \mathrm{~nm}$ which possess high performance in heattransfer. They possess good thermal characteristics and these are used as working fluids to improve the performance of the thermal system [9]. OmidMahian et al. [10] reviewed the possible utilization of different nanofluids in solar energy areas for different applications. In solar still, the water nanofluid improves the thermal transport and evaporation property. Kabeel et al. [11] analysed the effect of aluminium oxide nanoparticle onsolar still integrated with external condenser and observed that, the still production increased by $116 \%$.

\section{Experimental Work}

A single slopesingle basin solar still was fabricated using $3 \mathrm{~mm}$ thick GI sheet since it has the ability to resist corrosion. The base areaof the still was $0.25 \mathrm{~m} 2(0.5 \mathrm{~m} \times 0.5 \mathrm{~m})$.Fig 1.presents a schematic diagram of the single slope still. A transparent glass of $0.004 \mathrm{~m}$ thick was used as the top cover of the solar still and was inclined at an angle of $15^{\circ}$. Insulation was provided at the bottom and sides of the basin to prevent heat loss through conduction and convection respectively. Thermocol layer of $0.035 \mathrm{~m}$ thickness was provided at the sides of the still and the bottom area was placed above a wood slab of $0.005 \mathrm{~m}$ to avoid heat loss. The inner side of the basin was painted black to increase their absorptivity. Sealants were filled between the glass cover and the still at the top to prevent leakage. The solar still was arranged to face the south direction to maximize the reception of solar radiation. $\mathrm{K}$ type thermocouple was attached on the basin to measure the water temperature. Regular cleaning of salt deposition in the basin and dust on the glass cover was done to maintain the radiation absorption and transparency properties. The experimental setup is shown in Fig 2.

Metallic nanoparticles that possess high thermal conductivity are dispersed in the base fluid to create nanofluid. It enhances the rate of evaporation. In this research work, aluminium oxide $\left(\mathrm{Al}_{2} \mathrm{O}_{3}\right)$ and copper oxide 
$(\mathrm{CuO})$ were chosen for their high thermal conductivity. The stability of the nanofluid is one of the major challenges while utilizing metallic nanoparticles since it has the tendency to agglomerate when dispersed in a liquid[14-15]. Various concentrations were experimented and it was found that a concentration of $0.1 \%$ was found to be the optimized stability value for both nanofluids. The thermal conductivity of the nanofluid was determined using the transient hot wire method and the results are shown in Table 1.

Experiments were conducted with water and with water nanofluid in the rooftop of Velammal engineering college $(13.1497 \mathrm{oN}, 80.1919 \mathrm{oE})$ Tamil Nadu, India in the month of February 2017. It was ensure that the climatic conditions were almost similar on all the days of experimentation. Initially, water was filled to a depth of $4 \mathrm{~cm}$ and the readings such as temperature of the water and productivity of the still for each hour were noted. The experimentation was repeated with nanofluids and similar readings were taken.

TABLE1. Thermal conductivity of nanofluid

\begin{tabular}{cc}
\hline Fluid & Thermal Conductivity $(\mathbf{W} / \mathbf{m} \mathbf{K})$ \\
\hline Water & 0.591 \\
$\mathrm{Al}_{2} \mathrm{O}_{3}$ nanofluid & 0.654 \\
$\mathrm{CuOnanofluid}$ & 0.671 \\
\hline
\end{tabular}

\section{Result \& Discussion}

The variation of basin fluid temperature while using water, $\mathrm{Al}_{2} \mathrm{O}_{3}$ and CuOnanofluidare shown in Fig. 3 . Aluminium Oxide (A12O3) nanofluid at $0.1 \%$ concentration conducted more thermal energy and reached a peak temperature of $61.5^{\circ} \mathrm{C}$ at $2 \mathrm{pm}$. Copper Oxide $(\mathrm{CuO})$ nanofluid resulted in a peak temperature of $63.9^{\circ} \mathrm{C}$ at $2 \mathrm{pm}$. The base fluid water recorded a peak temperature of $54.4^{\circ} \mathrm{C}$ at $2 \mathrm{pm}$. It can be seen that the basin fluid temperature increases with addition of nanoparticles having higher thermal conductivity. The evaporation rate increases with addition of nanoparticles and the production rate also increases due to increase in temperature difference between the evaporating and conducting surface.

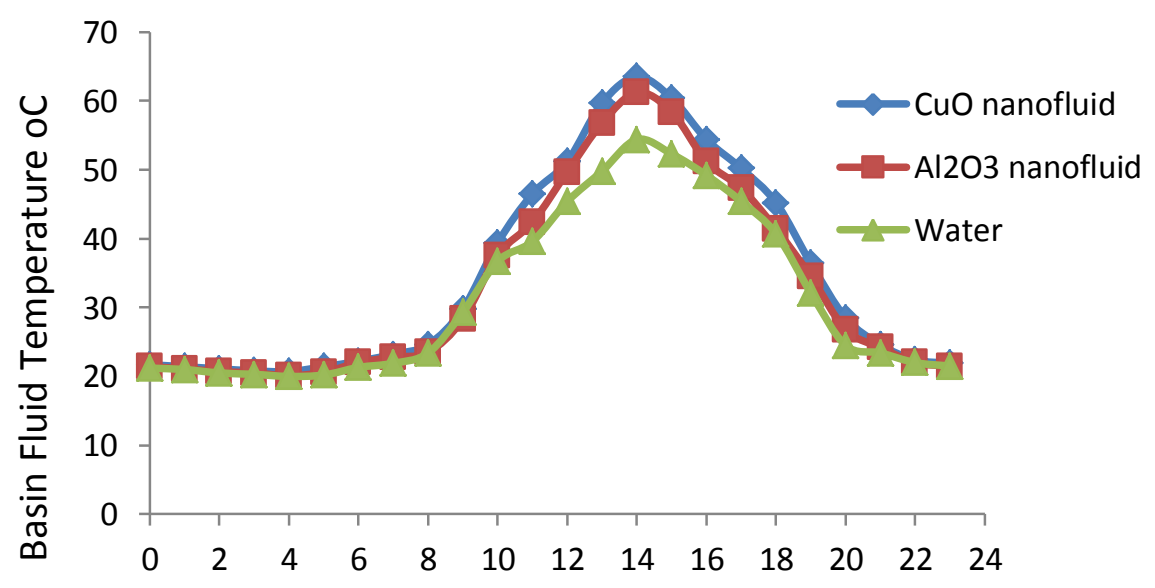

Time (hr)

Fig.3.Variationofbasinfluidtemperature.

The productivity of the solar still was measured every hour and the readings were noted. Fig. 4.shows the comparison of productivity while using water, $\mathrm{Al}_{2} \mathrm{O}_{3}$ and $\mathrm{CuOnanofluid}$. It can be clearly seen that the productivity rate was high for the still with copper oxidenanofluid followed aluminium oxide nanofluid and water. Due to the increase in the fluid temperature, the productivity of the solar still while using nanofluid 
increases. The peak productivity was observed around $2 \mathrm{pm}$ as $96 \mathrm{ml}, 107 \mathrm{ml}$ and $121 \mathrm{ml}$ for water, aluminium oxide and copper oxide respectively. Stability and thermal conductivity are the two major factors responsible for increased productivity while using copper oxide.

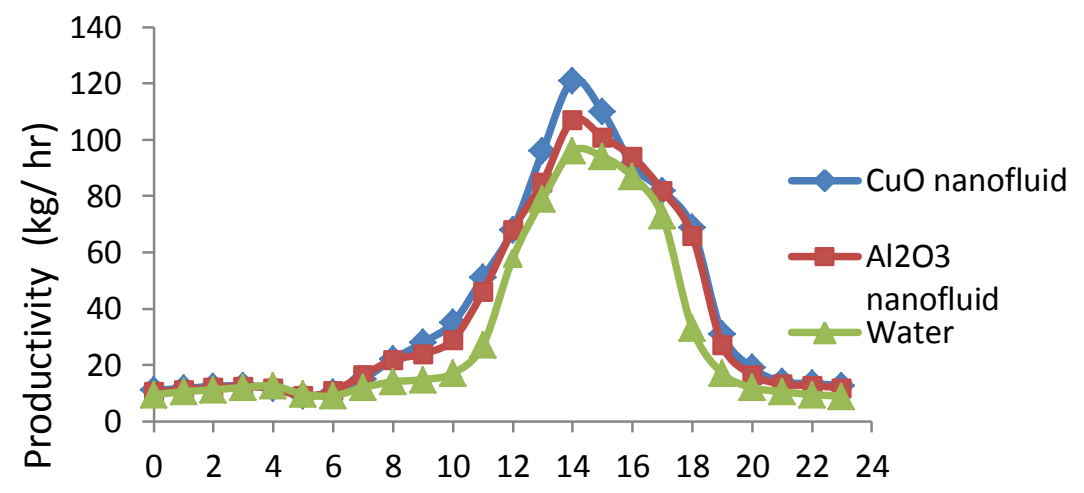

Time (hr)

Fig 4. Hourly Production Rate of the Solar Still

\section{Conclusion}

The following conclusions are inferred from the experimental investigation of using nanofluid in a solar still,

Addition of nanoparticles in water increases its thermal conductivity which in turn increases the temperature of the water resulting in higher evaporation rate. The thermal conductivity of the basin fluid increased by $10.65 \%$ and $13.44 \%$ while using $\mathrm{Al}_{2} \mathrm{O}_{3}$ and $\mathrm{CuOnanofluid.}$

The peak temperature of the basin fluid is reached around $2 \mathrm{pm}$ when the solar radiation reaches its maximum intensity. There is an increase of $13.05 \%$ and $17.46 \%$ in the peak temperature of thebasin fluid while using $\mathrm{Al}_{2} \mathrm{O}_{3}$ and $\mathrm{CuOnanofluid}$ respectively.

The productivity of the solar still increases by $26.36 \%$ and $34.61 \%$ respectively while using aluminium oxide and copper oxide nanofluid as the basin fluid instead of water. Thermal conductivity of the basin fluid is a major parameter of the solar still productivity. Thus the usage of nanofluid in solar still increases its performance by increasing the temperature of the basin fluid.

The major drawback while using nanofluids to enhance the performance of the solar still is their huge investment cost. With reduction in the price of the nanoparticles in the future, usage of nanofluid is one of the most effective and simple method to increase the productivity of solar still.

\section{References}

[1] H. A-hinai, Thermodynamic and economic considerations in solar desalination,Desalination 129 (2000) 63-89. https://doi.org/10.1016/S0011-9164(00)00052-7

[2] J. Burch, K.E. Thomas, An overview of water disinfection in developing countries and the potential of solar thermal water pasteurization, National Renewable Energy Laboratory, 1998.

https://doi.org/10.2172/567490

[3] Prakash M, Natarajan E, Numerical investigations: basin materials of a single basin and single slope solar still, Desalination and Water treatment (2015), pp $1-23$.

[4] Samuel Hansen R, Surya Narayanan C, KalidasaMuragavel, Performance analysis on inclined solar still with different new wick materials and wire mesh, Desalination 358 (2015), pp $1-8$. 
https://doi.org/10.1016/j.desal.2014.12.006

[5] T. Elango, A. Kannan, K. KalidasaMuragavel, Performance study on single basin single slop solar still with different nanofluids, Desalination 360 (2015) pp $45-51$.

https://doi.org/10.1016/j.desal.2015.01.004

[6] L. Sahota, G.N. Tiwari, Effect of nanofluids on the performance of passive double slope solar still: A comparative study using characteristic curve, Desalination 388 (2016) pp $9-21$.

https://doi.org/10.1016/j.desal.2016.02.039

[7] PanitapuBhramara, KoneruVijaya, Sagi Sri LalithaSwathi, Parik Ajay. Solar Distillation using nanomaterial. International Journal of Scientific Engineering and Technology Volume 3 (2014) pp583-87.

[8] Bhupendra Gupta, Prem Shankar, Raghavendra Kumar, PrashantBaredar, Performance enhancement using nano particles in modified passive solar still, Procedia Technology 25 (2016) pp 1209 - 1216.

https://doi.org/10.1016/j.protcy.2016.08.208

[9] R. Saidur, K.Y. Leong, H.A. Mohammad, A review on applications and challenges ofnanofluids, Sustainable Energy Review 15 (2011)pp 1646-1668. https://doi.org/10.1016/j.rser.2010.11.035

[10] OmidMahian, Ali Kianifar, Soteris A. Kalogirou, Ioan Pop, SomchaiWongwises, A review of the applications of nanofluids in solar energy, InternationalJournal of Heat Mass Transfer 57(2013)pp 582-594.

[11] A.E. Kabeel, Z.M. Omara, F.A. Essa, Enhancement of modified solar still integrated with external condenser using nanofluids: an experimental approach, EnergyConverison and Management 78 (2014) 493-498.

https://doi.org/10.1016/j.enconman.2013.11.013 